\title{
Small-Scale Solar-Bio-Hybrid Power Generation Using Brayton and Rankine Cycles
}

\author{
Mauricio Bustamante ${ }^{1}$, Abraham Engeda ${ }^{2}$ and Wei Liao ${ }^{3, *} \mathbb{D}$ \\ 1 School of Biosystems Engineering, University of Costa Rica, San José 11501-2060, Costa Rica; \\ mauricio.bustamante@ucr.ac.cr \\ 2 Mechanical Engineering, Michigan State University, East Lansing, MI 48824-1323, USA; engeda@egr.msu.edu \\ 3 Anaerobic Digestion Research and Education Center, Biosystems and Agricultural Engineering, \\ Michigan State University, East Lansing, MI 48824-1323, USA \\ * Correspondence: liaow@msu.edu; Tel.: +1-517-432-7205
}

\section{check for} updates

Citation: Bustamante, M.; Engeda, A.; Liao, W. Small-Scale Solar-BioHybrid Power Generation Using Brayton and Rankine Cycles. Energies 2021, 14, 472. https://doi.org/ $10.3390 /$ en14020472

Received: 30 September 2020

Accepted: 13 January 2021

Published: 17 January 2021

Publisher's Note: MDPI stays neutral with regard to jurisdictional claims in published maps and institutional affiliations.

Copyright: (c) 2021 by the authors. Licensee MDPI, Basel, Switzerland. This article is an open access article distributed under the terms and conditions of the Creative Commons Attribution (CC BY) license (https:// creativecommons.org/licenses/by/ $4.0 /$ )

\begin{abstract}
This study conducted a detailed technical analysis of small-scale solar-bio-hybrid power generation systems using Rankine (steam turbine) and Brayton (gas turbine) cycles. Thermodynamic models were developed to characterize the state of working fluid and select the most suitable solar collection technology for individual power generation systems. Net capacity factor of power generation and utilization efficiencies of solar and biogas energy were used as parameters to evaluate energy generation and conclude the preferred system configuration. The analysis concluded that the steam turbine system has better global efficiency $(67.7 \%)$ than the gas turbine system $(55.7 \%)$, while the gas turbine system has better electricity generation efficiency $(27.0 \%)$ than that $(5.6 \%)$ of the steam turbine system. The effects of different climates on the selection of suitable hybrid systems were also investigated to delineate suitability and feasibility of different hybrid systems. In addition, the method used in this study can also be applied to investigate and optimize other small-scale hybrid renewable energy generation systems.
\end{abstract}

Keywords: biogas; solar hybridization; net capacity factor; micro gas turbine; micro steam turbine

\section{Introduction}

Hybridization of power generation is a strategy that several different energy sources are collectively used to realize energy stability, electricity flexibility, and energy efficiency improvement. Many hybridization studies have focused on combining solar energy with fossil fuels [1,2], in which the concentrated solar energy is used as the heat source to raise temperature of working fluid prior to fuel combustion and improve energy generation efficiency $[3,4]$. With increasing attention on utilization of more renewable resources for power generation, combining concentrated solar energy with biogas becomes a potential alternative to solar-fossil-fuel hybrid power generation [5,6]. However, current research and development on solar-bio-hybridization have mainly focused on large power generation ranging from a few hundred $\mathrm{kW}$ to several MW [6-9]. Only a few studies reported solar-bio-hybrid micro-power (less than $100 \mathrm{kw}$ ) generation [10,11]. Considering end-users of such power generation technologies, there is a high demand on small-scale distributed renewable systems for farm/food operations and remote villages/towns. Therefore, indepth studies on small-scale solar-bio-hybrid power generation are very much needed to extend the hybridization concept to a wider range of applications.

Anaerobic digestion (AD) is an existing biological conversion process that has been proven effective on converting wet organic wastes into biogas (containing methane and carbon dioxide). It is capable of producing clean electricity while also alleviating many of the environmental concerns associated with the wastes (odor, greenhouse gas emission, and ground water contamination) [12]. In addition, different from large power plant operations, $\mathrm{AD}$ can be set up in small or medium scale for biogas generation such as wastewater 
treatment plants, food processing plants, and animal farms (i.e., more than $80 \%$ of the U.S. animal farms have less than 500 animals per farm) [13]. Combining AD operation and solar thermal collection to develop small-scale solar-biogas-hybrid power generation could provide a win-win solution to treat organic wastes and satisfy the energy demand of residential and farm operations.

Solar thermal technologies are classified as low-, medium-, and high-temperature solar thermal collection [14]. Due to the temperature requirement of turbines for power generation, medium- and high-temperature solar thermal collections are suitable for the hybridization system. Medium-temperature (approximately $400{ }^{\circ} \mathrm{C}$ ) solar thermal technologies often use a parabolic trough to collect solar energy. The central tower receiver and parabolic dish are the high-temperature (more than $500^{\circ} \mathrm{C}$ ) solar thermal technologies. Considering the size of power plants, central tower receiver is mainly used by solar thermal power plants to generate electricity in the magnitude of $100 \mathrm{MW}$ or above. It requires large solar fields, and the operating temperature typically ranges from $600{ }^{\circ} \mathrm{C}$ to $1400{ }^{\circ} \mathrm{C}$ [14]. Meanwhile, the parabolic dish and parabolic trough are the solar thermal technologies that could be used for small- and medium-scale power operations and generate electricity in the magnitude of $\mathrm{kW}$.

In order to investigate and develop small-scale solar-bio-hybrid power generation, $30 \mathrm{~kW}$ power generation systems including three-unit operations of AD, a solar thermal collector, and an engine are comprehensively analyzed in this study. Biogas from AD and thermal energy from solar collection are used as the energy sources to generate electricity and heat. Gas and steam turbines as engine units are compared to conclude the preferred one for the small-scale solar-bio-hybrid system at different locations. Net capacity factor (the ratio of the energy output to the total energy generation of the system in a given time duration) and solar and biogas utilization factors (percentage of each energy source used to generate the electrical energy) are used as parameters to evaluate energy generation and optimize system configuration.

\section{The Studied Small Solar-Bio-Hybrid Power Generation Systems}

Thermodynamic models were established to analyze solar-bio-hybrid systems with gas and steam turbines, respectively (Figure 1). Biogas production for the studied systems was based on a biogas plant using thermophilic AD on the mixture feed of dairy manure and food wastes (90:10 ratio, 5\% total solids) [15]. The AD with a culture temperature of $45{ }^{\circ} \mathrm{C}$ and a hydraulic retention time (HRT) of 20 days produced $0.64 \mathrm{~m}^{3}$ biogas per $\mathrm{m}^{3}$ digestion solution per day with $0.38 \mathrm{~m}^{3}$ methane (the lower heating value (LHV) of biogas is $23 \mathrm{MJ} / \mathrm{m}^{3}$ [16]) and $0.26 \mathrm{~m}^{3}$ carbon dioxide. The steam turbine includes a condenser in a close-loop circuit (Figure 1a). The gas turbine uses a regenerator to transfer energy from exhaust gases into compressed air in an open-loop air circuit (Figure 1c). Both systems contain a water heat storage to collect energy from the thermodynamic cycle to satisfy the heat demand of the anaerobic digester (maintaining digestion temperature and heating the influent). Configurations of solar-bio-hybrid power generation systems (which include a secondary heat source of solar energy) are slightly more complicated than turbine power generation systems, in which molten salt is used as the short-term solar thermal storage [17]. In the solar-bio-hybrid system with a steam turbine, a heat exchanger is implemented to use heat from the solar thermal storage to heat the working fluid prior to the boiler. The boiler further heats the working fluid to generate superheated steam for the steam turbine (Figure 1b). The solar-bio-hybrid system with a gas turbine uses heat from the solar thermal storage to raise temperature of the hot air from the regenerator in the heat exchanger before being mixed with biogas in the burner to generate heat (Figure 1d). The analyses are based on a constant electricity generation of $30 \mathrm{~kW}$ for all the studied systems. Operational parameters of the thermodynamic models are listed in Table 1. 


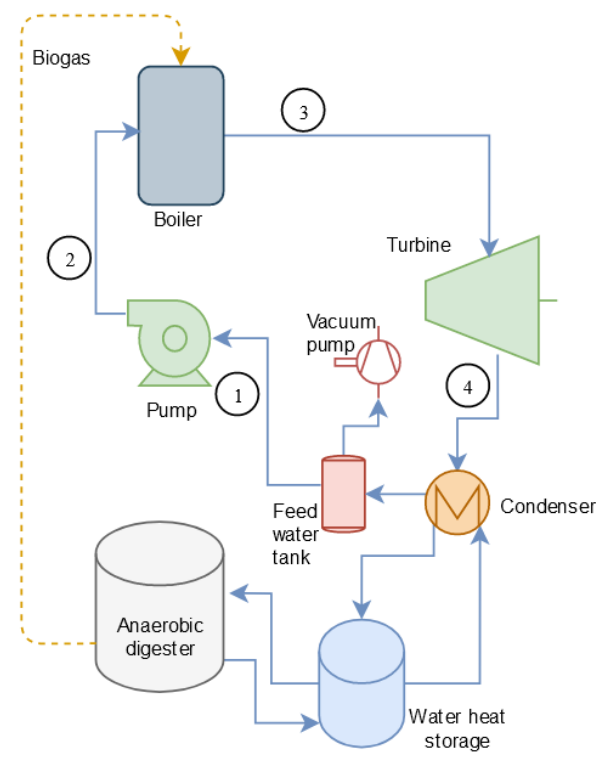

(a)

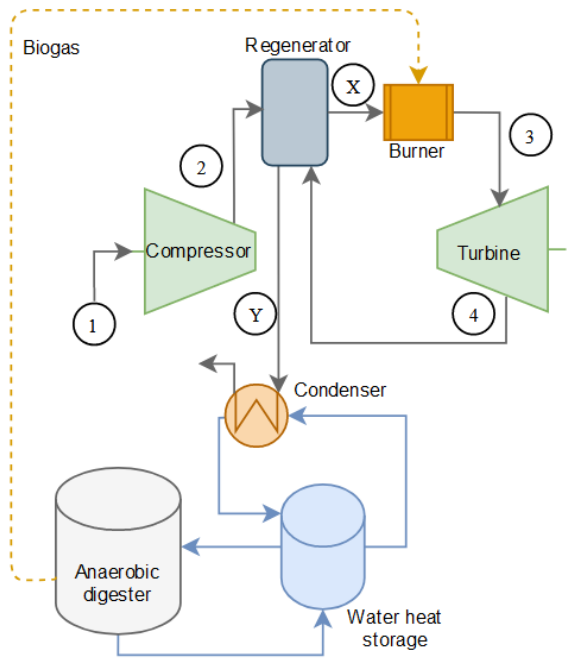

(c)

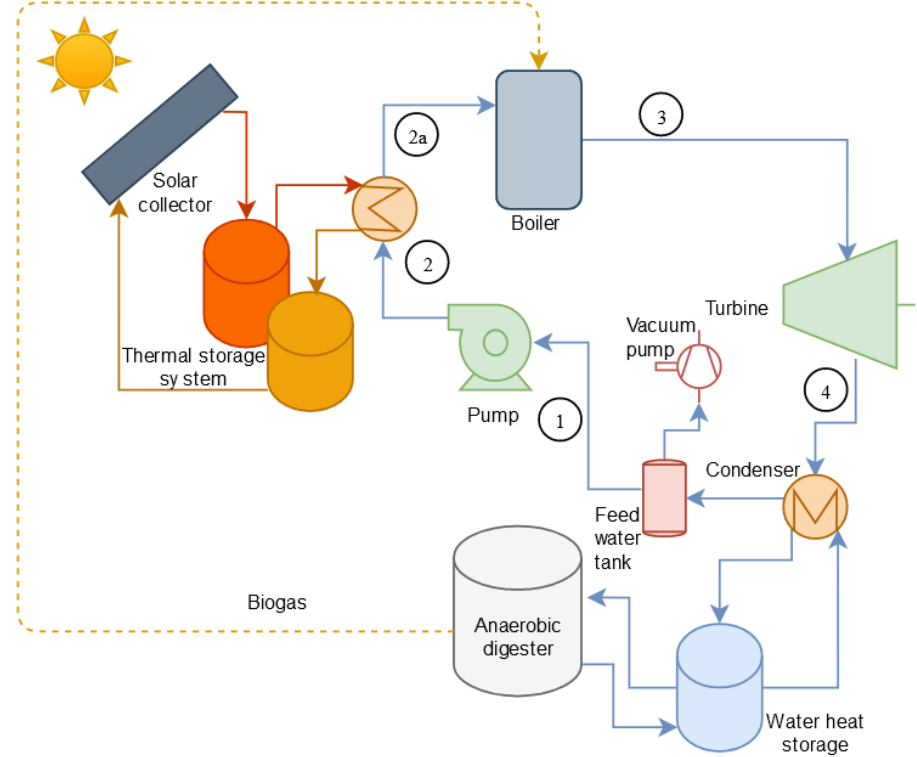

(b)

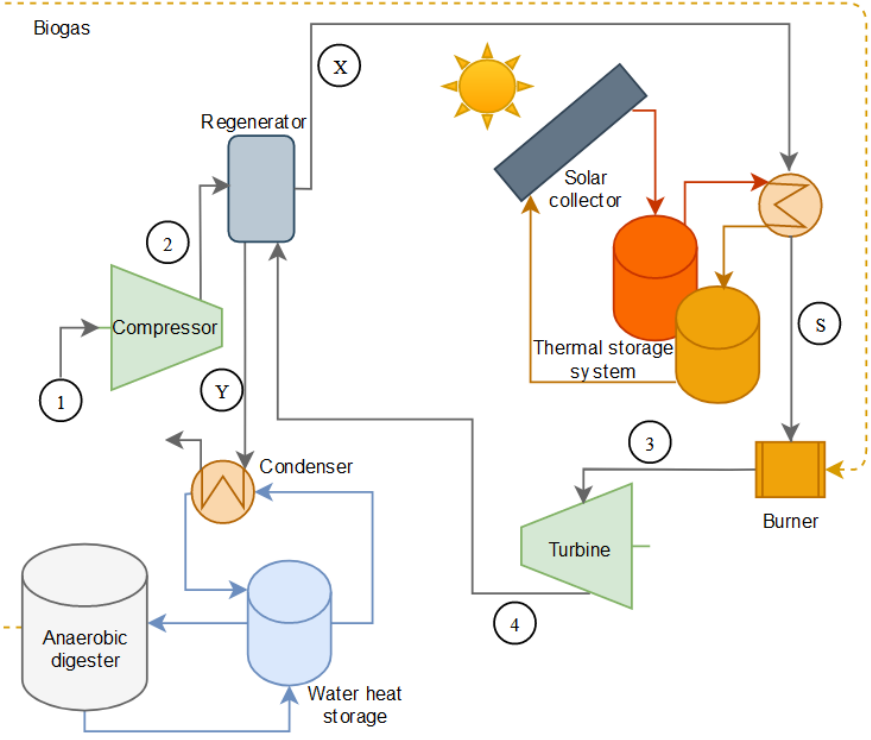

(d)

Figure 1. Schematics of the studied solar-bio-hybrid power generation systems: (a) the biogas steam turbine; (b) the solar-bio-hybrid power system with a steam turbine; (c) the biogas gas turbine; (d) the solar-bio-hybrid power system with a gas turbine.

Table 1. Operational parameters of $30-\mathrm{kW}$ steam and gas turbines *.

\begin{tabular}{cccc}
\hline System & Parameter & Unit & Value \\
\hline \multirow{3}{*}{ Steam Turbine $(30 \mathrm{~kW})$} & Steam Requirement & $\mathrm{kg} / \mathrm{s}$ & 0.163 \\
\cline { 2 - 4 } & Steam Inlet Pressure (Turbine) & bar & 12 \\
\cline { 2 - 4 } & Condenser Inlet Pressure & bar & 0.1 \\
\cline { 2 - 4 } & Steam Inlet Temperature Tturbine) & ${ }^{\circ} \mathrm{C}$ & 200 \\
\cline { 2 - 4 } & Vacuum Pump Power & $\mathrm{W}$ & 500 \\
\cline { 2 - 4 } & Steam Outlet Pressure (Turbine) & bar & 0.1 \\
\hline
\end{tabular}


Table 1. Cont.

\begin{tabular}{cccc}
\hline System & Parameter & Unit & Value \\
\hline & Air Mass Flow & $\mathrm{kg} / \mathrm{s}$ & 0.31 \\
\cline { 2 - 4 } & Gas Inlet Temperature (Turbine) & $\mathrm{K}$ & 1117 \\
\cline { 2 - 4 } & Compression Ratio & - & 3.2 \\
\cline { 2 - 4 } Gas Turbine (30 kW) & Air Inlet Temperature (Compressor) & $\mathrm{K}$ & 288.15 \\
\cline { 2 - 4 } & Gas Temperature After Expansion & $\mathrm{K}$ & 866 \\
\cline { 2 - 4 } & Turbine Outlet Pressure & $\mathrm{kPa}$ & 103 \\
\cline { 2 - 4 } & Turbine Inlet Pressure & $\mathrm{kPa}$ & 309.7 \\
\cline { 2 - 4 } & Compressor Outlet Pressure & $\mathrm{kPa}$ & 319.298 \\
\cline { 2 - 4 } & Compressor Inlet Pressure & $\mathrm{kPa}$ & 101.325 \\
\hline
\end{tabular}

*: The parameters are from the commercial steam and gas engines [18-22].

Rankine cycle was used to simulate performance of the biogas steam turbine (Figure 2a). The working fluid of water is pumped into the boiler that is maintained at constant pressure (Figure 1a,b). Power consumption of the pump and the enthalpy at point 2 in Figure $1 \mathrm{a}$ and $b$ are calculated by:

$$
\begin{gathered}
w_{P}=v_{l} \cdot\left(P_{i}-P_{o}\right) \cdot 100 / \eta_{p} \\
h_{2}=h_{1}+w_{P}
\end{gathered}
$$

where $w_{P}$ is the pump work $\left(\mathrm{kJ} / \mathrm{kg}_{\text {water }}\right), \eta_{p}$ is the pump efficiency (38.8\% from a Grundfos pump Model CR 1-19, considering electrical, mechanical and hydraulic losses), $v_{l}$ is the specific volume $\left(\mathrm{m}^{3} / \mathrm{kg}\right), P_{i}$ and $P_{o}$ are the inlet and outlet pressure in the turbine, $h$ is the enthalpy at given temperature and pressure conditions $\left(\mathrm{kJ} / \mathrm{kg}_{\text {water }}\right)$. To satisfy the required temperature and pressure of feed water for the selected $30 \mathrm{~kW}$ steam engine, the heat input $\left(Q_{F}^{s}\right)$ is calculated as follows:

$$
Q_{F}^{s}=\frac{\dot{m}_{\mathrm{H}_{2} \mathrm{O}} \cdot\left(h_{3}-h_{2}\right)}{\eta_{b}}
$$

where $\eta_{b}$ is the fuel-to-steam boiler efficiency (0.80) [23]. Cleaver Brooks model CB 40 with a dryback integral burner was selected considering both radiation and convection losses. It has $15 \%$ excess air in the exhaust flue gas at $100 \%$ firing rate.

Fuel-to-electricity efficiency of the system is calculated based on fluid properties in inlets and outlets of the turbine and pump:

$$
\eta_{T}^{s}=\frac{30 \mathrm{~kW}}{Q_{F}^{s}}
$$

The heat extracted $\left(Q_{H}{ }^{s}\right)$ for digester heating is calculated by:

$$
Q_{H}{ }^{s}=\dot{m}_{H_{2} O} \cdot h_{g f} \cdot \eta_{c}
$$

where $\eta_{c}$ is the condenser effectiveness (set at 0.85 ), and $h_{g f}$ is the heat of condensation of water.

The simulation results for the steam turbine are presented in Table 2. Enthalpies at points 1, 2, and 3 (Figures 1a and 2a) are 191.81, 194.91, and $2816.1 \mathrm{~kJ} / \mathrm{kg}$, respectively. Temperatures at points 2 and 4 are $46.31^{\circ} \mathrm{C}$ and $45.81^{\circ} \mathrm{C}$. The corresponding heat input and heat extraction are 534.06 and $331.56 \mathrm{~kW}$, respectively. Efficiencies for this particular equipment under the working parameters show that $5.62 \%$ of the biogas energy is transformed into electricity, and $62.08 \%$ of the biogas energy is turned into useful heat. 


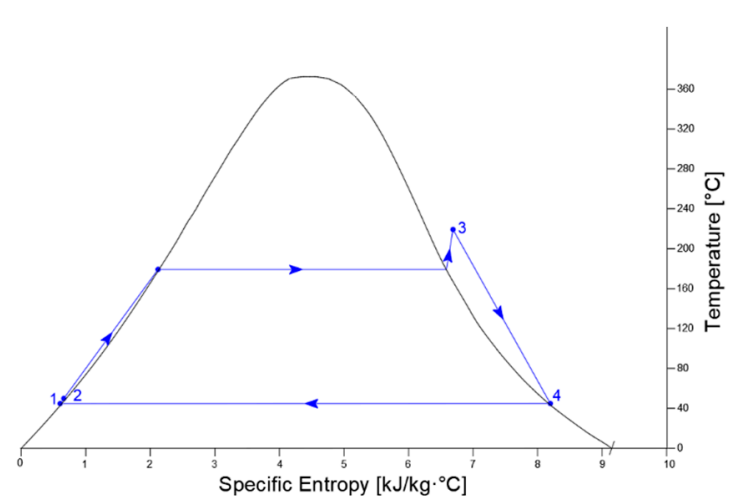

(a)

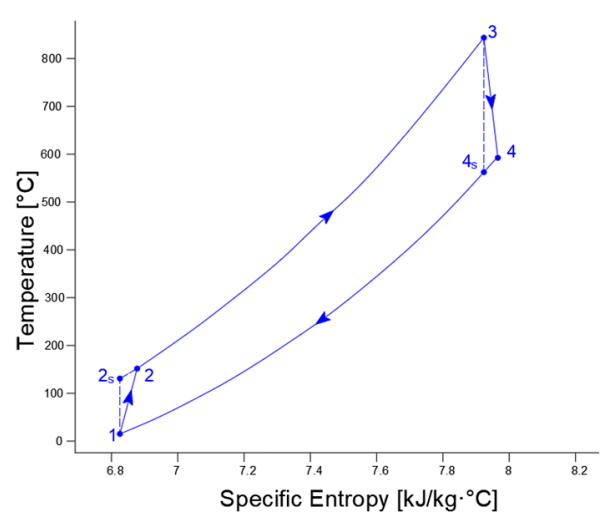

(b)

Figure 2. Temperature-Entropy (T-S) diagrams: (a) steam turbine; (b) gas turbine.

Table 2. The simulation results of a $30-\mathrm{kW}$ steam turbine.

\begin{tabular}{ccc}
\hline Parameter & Unit & Simulation Results \\
\hline$w_{P}$ & $\mathrm{~kJ} / \mathrm{kg}_{\text {water }}$ & 3.09 \\
\hline$h_{1}$ & $\mathrm{~kJ} / \mathrm{kg}_{\text {water }}$ & 191.81 \\
\hline$h_{2}$ & $\mathrm{~kJ} / \mathrm{kg}_{\text {water }}$ & 1941 \\
\hline$h_{3}$ & $\mathrm{~kJ} / \mathrm{kg}_{\text {water }}$ & 2816.1 \\
\hline$h_{4}$ & $\mathrm{~kJ} / \mathrm{kg}_{\text {water }}$ & 2585.8 \\
\hline$T_{2}{ }^{s}$ & ${ }^{\circ} \mathrm{C}$ & 46.31 \\
\hline$T_{4}{ }^{s}$ & ${ }^{\circ} \mathrm{C}$ & 45.81 \\
\hline$\eta_{T}{ }^{s}$ & - & 0.0562 \\
\hline$Q_{F}{ }^{s}$ & $\mathrm{~kW}$ & 534.06 \\
\hline$Q_{H}{ }^{s}$ & $\mathrm{~kW}$ & 331.56 \\
\hline
\end{tabular}

In the solar-bio-hybrid steam power system (Figure 1b), solar thermal energy reduces the amount of heat required by the boiler, and consequently decreases the biogas consumption. If there is enough solar radiation, the solar thermal energy heats the water up to $T_{2}{ }^{S}=200{ }^{\circ} \mathrm{C}$. If there is not enough solar radiation, the boiler provides partial energy to adjust the steam quality for turbine operation.

As for the gas turbine, Brayton cycle (Figure 2b) was used to simulate the turbine performance [24]. The temperature $\left(T_{2}^{g}\right)$ after the compressor (point 2 in Figure $1 \mathrm{c}, \mathrm{d}$ and Figure 2b) was calculated by:

$$
\begin{gathered}
T_{2}^{g}=T_{1}^{g} \cdot\left(1+\frac{1}{\varepsilon_{c}} \cdot\left(r_{P}^{\alpha}-1\right)\right) \\
\alpha=\frac{\gamma-1}{\gamma}
\end{gathered}
$$

where $r_{p}$ is the pressure ratio between inlet and outlet in the compressor, $\gamma$ is the ratio of the specific heat at constant pressure and the specific heat at constant volume, $\varepsilon_{c}$ is the compressor isentropic efficiency $\left(\varepsilon_{c}=0.83[19,22]\right)$. The temperature after the regenerator (Point $x$ in Figure 1c,d) is given by:

$$
T_{x}^{g}=T_{4}^{g} \cdot \varepsilon_{R}+T_{2}^{g} \cdot\left(1-\varepsilon_{R}\right)
$$


where $\varepsilon_{R}$ is the regenerator effectiveness (0.90 [20]). The heat input $\left(Q_{F}^{g}\right)$ to the burner is calculated by:

$$
Q_{F}^{g}=\frac{\dot{m}_{a i r} \cdot C p_{3} \cdot\left(T_{3}^{G}-T_{x}^{G}\right)}{\varepsilon_{H C}}
$$

where $\dot{m}_{\text {air. }}$ is the air mass flow, $C p_{3}$ is the average specific heat between $C p_{\circledast} T_{3}^{g}$ and $C p_{@} T_{x}^{g}(\mathrm{~kJ} / \mathrm{kg} \cdot \mathrm{K})$, and $\varepsilon_{H C}$ is the burner efficiency $\left(\varepsilon_{H C}=0.934\right.$, obtained from a fuel requirement of $415 \times 10^{3} \mathrm{~kJ} / \mathrm{hr}$ of LHV based on [21]). The temperature of the exhaust gases after the regenerator (Point $Y$ in Figure $1 c, d$ ) is given by:

$$
T_{y}^{g}=T_{2}^{g} \cdot \varepsilon_{R}+T_{4}^{g} \cdot\left(1-\varepsilon_{R}\right)
$$

The fuel-to-electricity efficiency for the gas micro turbine system is:

$$
\eta_{T^{g}}^{g}=\frac{30 \mathrm{~kW}}{Q_{F}^{g}}
$$

The extracted heat $\left(Q_{H}^{g}\right)$ from the exhaust gases for digester heating is calculated by:

$$
Q_{H}^{g}=\dot{m}_{a i r} \cdot C p_{y} \cdot\left(T_{y}^{g}-T_{F}^{g}\right) \cdot \varepsilon_{L}
$$

where $C p_{y}$ is the average specific heat between $C p_{@} T_{y}^{g}$ and $C p_{@} T_{F}^{g}(\mathrm{~kJ} / \mathrm{kg} \cdot \mathrm{K}), T_{F}^{g}$ is the temperature of the exhaust gases (assumed as $60^{\circ} \mathrm{C}$ ) and $\varepsilon_{L}$ is the effectiveness of the heat exchanger and set at 0.75 .

Simulation results for the gas turbine analysis are listed in Table 3. At a constant air inlet temperature, input and extracted heat are $111.31 \mathrm{~kW}$ and $32.01 \mathrm{~kW}$, respectively. The compression increases air temperature from $288 \mathrm{~K}$ at point 1 to $424.78 \mathrm{~K}$ at point 2 . The regenerator further increases air temperature to $821.88 \mathrm{~K}$ at point $X$ before mixing with biogas in the burner. The gas turbine unit uses $26.95 \%$ of biogas for electricity generation, and $28.76 \%$ of biogas to generate heat.

Table 3. Operational parameters for a $30-\mathrm{kW}$ gas turbine.

\begin{tabular}{ccc}
\hline Parameter & Unit & Simulation Results \\
\hline$\eta_{T^{g}}^{g}$ & - & 0.2695 \\
\hline$T_{2}^{g}$ & $\mathrm{~K}$ & 424.78 \\
\hline$T_{x}^{g}$ & $\mathrm{~K}$ & 821.88 \\
\hline$T_{y}^{g}$ & $\mathrm{~K}$ & 468.91 \\
\hline$Q_{F}^{g}$ & $\mathrm{~kW}$ & 111.31 \\
\hline$Q_{H^{g}}$ & $\mathrm{~kW}$ & 32.01 \\
\hline
\end{tabular}

With the addition of solar thermal energy $\left(Q_{\text {solar }}(\mathrm{kW})\right)$ (Figure $\left.1 \mathrm{~d}\right)$, heat demand for the biogas burner is also reduced. The temperature after the solar collector is calculated as follows:

$$
T_{s}^{g}=T_{x}^{g}+\frac{Q_{\text {solar }}}{\dot{m}_{\text {air }} \cdot C p_{2 a}}
$$

Where $C p_{2 a}$ is the average specific heat between $C p_{@} T_{x}^{g}$. and $C p_{@} T_{3}^{g}(\mathrm{~kJ} / \mathrm{kg} \cdot \mathrm{K})$.

In addition, due to seasonal and geographical variation of solar radiation, location of the studied systems has a great impact on their performance. Direct normal irradiance (DNI) and ambient temperature are decreased following the increase in latitude. Therefore, two locations of Lansing (MI) and Phoenix (AZ) in the United States with significant different temperatures and solar radiations were selected to study the impact. Figure 3 represents solar radiation and ambient temperature in a year for both locations $[25,26]$. 


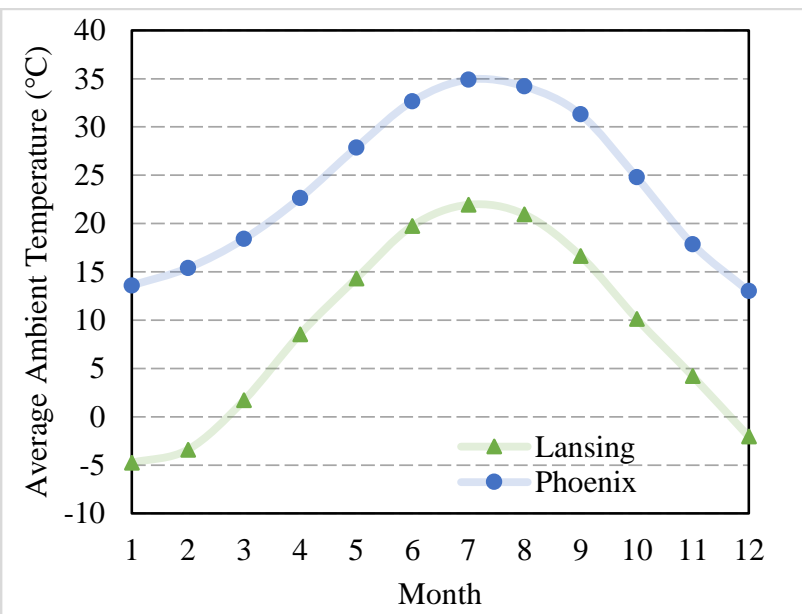

(a)

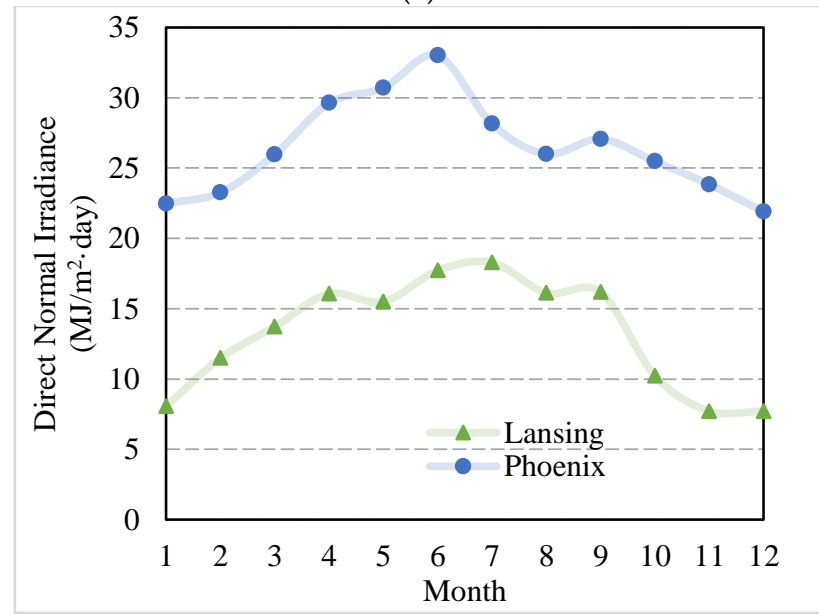

(b)

Figure 3. Local temperature and irradiance at Lansing and Phoenix. (a) Monthly average temperature and (b) direct normal irradiance (DNI)

\subsection{Relationship between Solar Energy, Net Capacity Factor, and Ratio of Solar Energy to Biogas Energy}

Biogas consumption for solar-bio-hybrid power systems (steam and gas turbines) depends on the usage of solar energy (the heat input from solar energy) and the net capacity factor of power generation. Effects of capacity factor and solar usage on digester volume and solar energy requirement for solar-bio-hybrid steam and gas turbine systems are presented in Figure 4. With the increase in net capacity factor and solar usage, solar energy demands for both systems linearly increased. Meanwhile, the hybrid steam engine system demands more solar energy than the hybrid gas turbine system (Figure 4a,b). For instances of full utilization of solar energy $(100 \%$ solar usage and 1 net capacity factor) to power the hybrid systems, the hybrid steam turbine system requires $36914 \mathrm{MJ} /$ day solar energy which is much higher than the demand from the hybrid gas turbine system ( $8978 \mathrm{MJ}$ /day). Meanwhile, the required digester volume to generate biogas for $30 \mathrm{~kW}$ electricity generation increased with increase in net capacity factor and decrease in solar usage for both systems, and the hybrid steam engine system needs more digester volume than the hybrid gas engine system (Figure $4 \mathrm{c}, \mathrm{d}$ ). At the point of $0 \%$ solar usage and 1 net capacity factor, the hybrid steam engine system needs $3134 \mathrm{~m}^{3}$ of digester volume, while the hybrid gas turbine just needs $651 \mathrm{~m}^{3}$ of digester volume. 


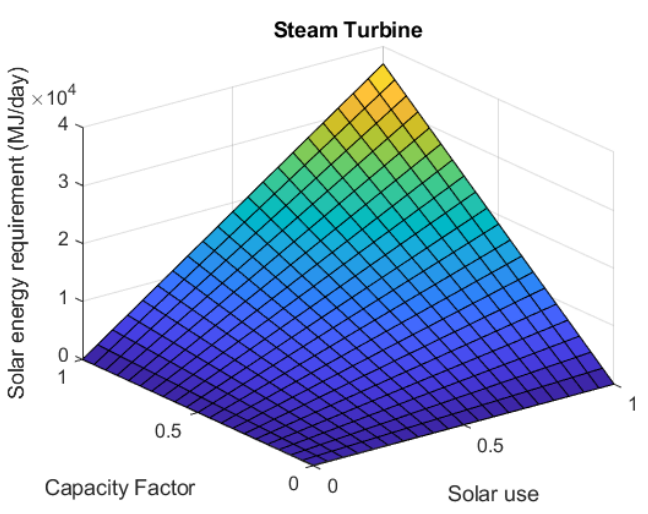

(a)

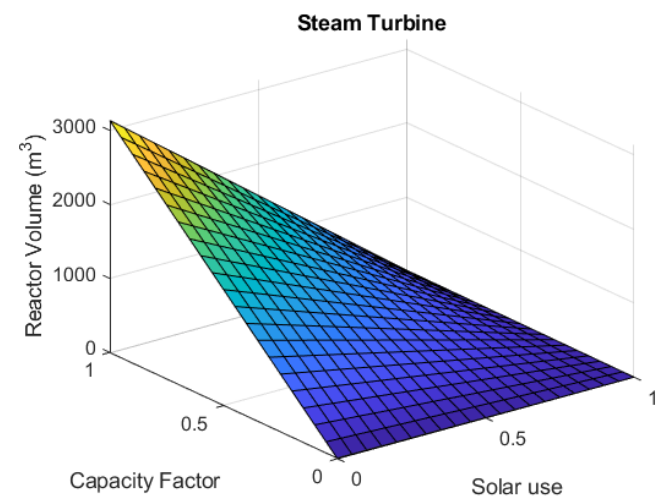

(c)

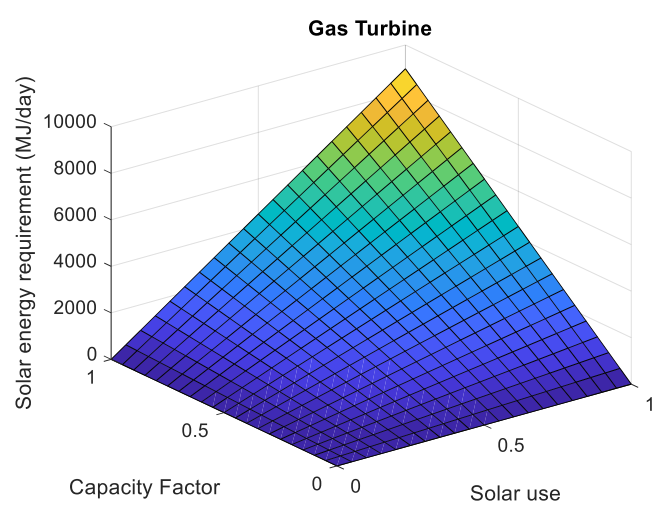

(b)

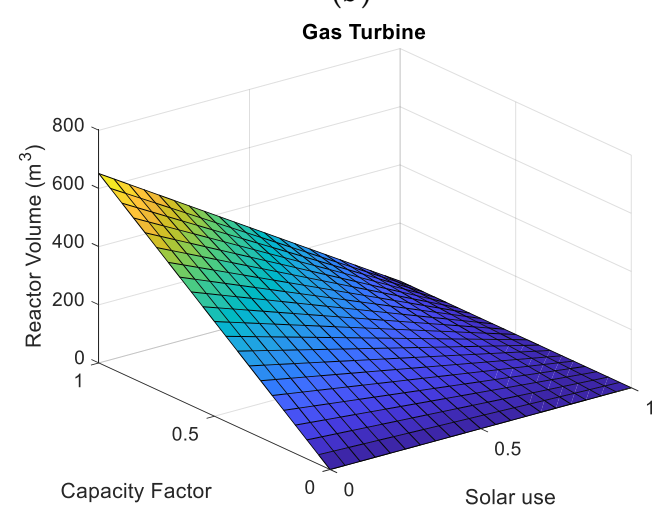

(d)

Figure 4. Effects of net capacity factor and solar usage on digester volume and solar energy requirement for different solar-bio-hybrid systems: (a) solar energy requirement for the solar-bio-hybrid steam turbine system; (b) solar energy requirement for the solar-bio-hybrid gas turbine system; (c) digester volume for the solar-bio-hybrid steam turbine system; (d) digester volume for the solar-bio-hybrid gas turbine system.

\subsection{Energy Requirement for Biogas Production}

Thermal Energy Requirement of Biogas Production

Thermal energy is needed by anaerobic digestion to heat the feed and maintain the culture temperature at $45^{\circ} \mathrm{C}$. The energy requirement per day $E_{r e q}$ in (MJ/day) [27] to heat the influent is:

$$
E_{r e q}{ }^{\text {in }}=\frac{V_{A D}}{H R T} \cdot \rho_{i n f} \cdot C_{p} \cdot\left(T_{A D}-T_{\text {inf }}\right) \div 1 \times 10^{6}
$$

where $V_{A D}$ is the digester volume $\left(\mathrm{m}^{3}\right), H R T$ is the hydraulic retention time (days), $\rho_{\text {inf }}$ is the feed density $\left(1220 \mathrm{~kg} / \mathrm{m}^{3}\right), C_{p}$ is the feed specific heat $\left(3606 \mathrm{~J} / \mathrm{kg} \cdot{ }^{\circ} \mathrm{C}\right), T_{A D}$ is the culture temperature $\left(45^{\circ} \mathrm{C}\right), T_{\text {inf }}$ is the feed temperature and assumed to be the same with ambient temperature once the ambient temperature is above $4^{\circ} \mathrm{C}$ (the feed temperature is set at $4{ }^{\circ} \mathrm{C}$ once the ambient temperature is below $4{ }^{\circ} \mathrm{C}$ ). The energy requirement to maintain the culture temperature $E_{\text {req }} A D$ (MJ/hour) [28] is calculated as follow:

$$
E_{r e q}^{A D}=\frac{A r \cdot\left(T_{A D}-T_{\text {inf }}\right)}{R_{12}} \cdot 3600 \div 1 \times 10^{6}
$$

where $A r$ is the digester surface area $\left(\mathrm{m}^{2}\right)$ (the ratio for height:diameter is 2$), R_{12}$ is the R-value for the insulation $\left(2.1133^{\circ} \mathrm{C} \cdot \mathrm{m}^{2} / \mathrm{W}\right)$.

Solar utilization value is selected based on the balance between thermal energy required by the anaerobic digester and thermal energy generated in the power generation 
system at a given net capacity factor. The thermal energy generated in the power system $E_{t h}{ }^{g e n}(\mathrm{MJ} /$ day) is calculated as follows:

$$
E_{t h}{ }^{g e n}=Q_{H}^{*} \cdot N C F \cdot(24 \cdot 3600) \div 1 \times 10^{3}
$$

where $Q_{H}{ }^{*}$ is the heat generated $\left(Q_{H}^{g}\right.$ or $\left.Q_{H}^{s}\right)(\mathrm{kW})$, and NCF is the net capacity factor. The energy requirement per day $E_{t h}{ }^{r e q}(\mathrm{MJ} /$ day) can be expressed as:

$$
E_{t h}{ }^{r e q}=E_{r e q}{ }^{i n}+\sum_{n=0}^{23}\left(E_{r e q}^{A D}\right)_{n}
$$

Substituting Equation (15) and Equation (16) into Equation (17), and considering that:

$$
\begin{gathered}
V_{A D}=\frac{\dot{V}_{\text {biogas }}}{\eta_{\text {biogas }}} \\
\dot{V}_{\text {biogas }}=\frac{E_{\text {biogas }}}{H C} \\
E_{\text {biogas }}=\frac{Q_{F}^{*} \cdot(1-S U) \cdot(C F \cdot 24 \cdot 3600)}{1000}
\end{gathered}
$$

The energy requirement per day can be calculated:

$$
E_{\text {th }}{ }^{\text {req }}=\left(\frac{Q_{F}^{*} \cdot(1-S U) \cdot(C F \cdot 24 \cdot 3600)}{1000 \cdot H C \cdot \eta_{\text {biogas }}}\left(\frac{1}{H R T}\right) \cdot \rho_{\text {inf }} \cdot C_{p} \cdot\left(T_{A D}-T_{\text {inf }}\right) \div 1 \times 10^{6}\right)+\sum_{n=0}^{23}\left(E_{\text {req }} A D\right)_{n}
$$

where $\dot{V}_{\text {biogas }}$ is the biogas requirement $\left(\mathrm{m}^{3} /\right.$ day), $\eta_{\text {biogas }}$ is the biogas productivity ( $\mathrm{m}^{3}$ biogas $/$ $\mathrm{m}^{3}$ digester day), $E_{\text {biogas }}$ is the energy provided by biogas (MJ/day), HC is the heat of combustion of biogas $\left(23 \mathrm{MJ} / \mathrm{m}^{3}\right), Q_{F}{ }^{*}$ is the heat input $\left(Q_{F}{ }^{s}\right.$ or $\left.Q_{F}^{g}\right)(\mathrm{kW})$, and $S U$ is the solar utilization factor. The solar utilization factor can be calculated by a thermal energy balance:

$$
E_{t h}{ }^{g e n}=E_{t h}{ }^{r e q}
$$

For instance of a given net capacity factor of 0.5 , the relationship between solar utilization and required thermal energy by $\mathrm{AD}$ is shown in Figure 5. To satisfy energy demands

\begin{tabular}{|c|c|c|c|c|}
\hline \multirow{2}{*}{ Location } & \multicolumn{2}{|c|}{ Digester Volume $\left(\mathrm{m}^{3}\right)$} & \multicolumn{2}{|c|}{ Biogas Production $\left(\mathrm{m}^{3} /\right.$ day $)$} \\
\hline & Steam & Gas & Steam & Gas \\
\hline Lansing & 1300.8 & 113.61 & 835.3 & 72.95 \\
\hline Phoenix & 1567.2 & 144.9 & 1006.4 & 93.05 \\
\hline
\end{tabular}
of heating the influent and maintaining the digestion temperature, $17.05 \%$ and $65.10 \%$ of solar utilization are required for the steam and gas turbines at Lansing, respectively, and the corresponding values at Phoenix are $0 \%$ and $55.49 \%$. These values at the capacity factor of 0.5 are used as the base numbers to select anaerobic digester volume and solar collector for each location and power system (Table 4).

Table 4. Digester volume and daily biogas production for selected solar utilization ${ }^{\text {a }}$.

a. The net capacity factor of 0.5 is used to calculate these numbers. 


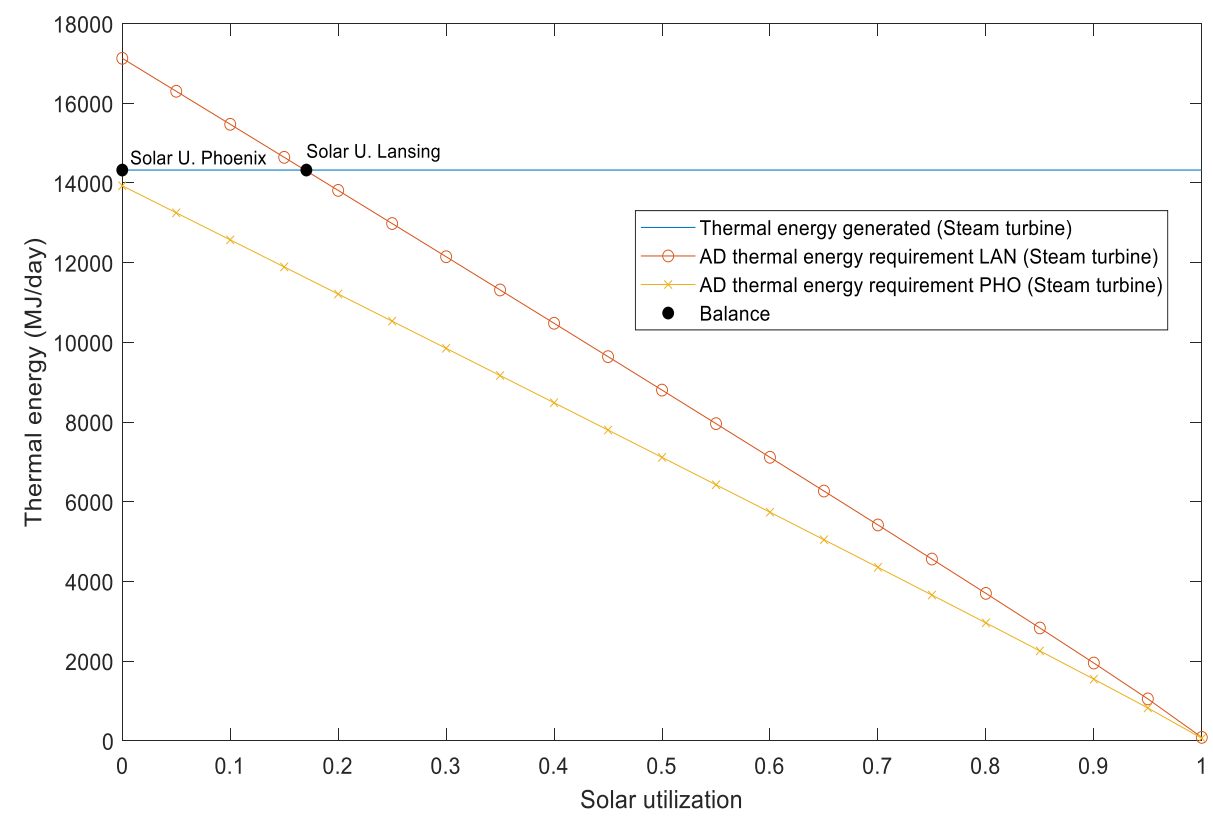

(a)

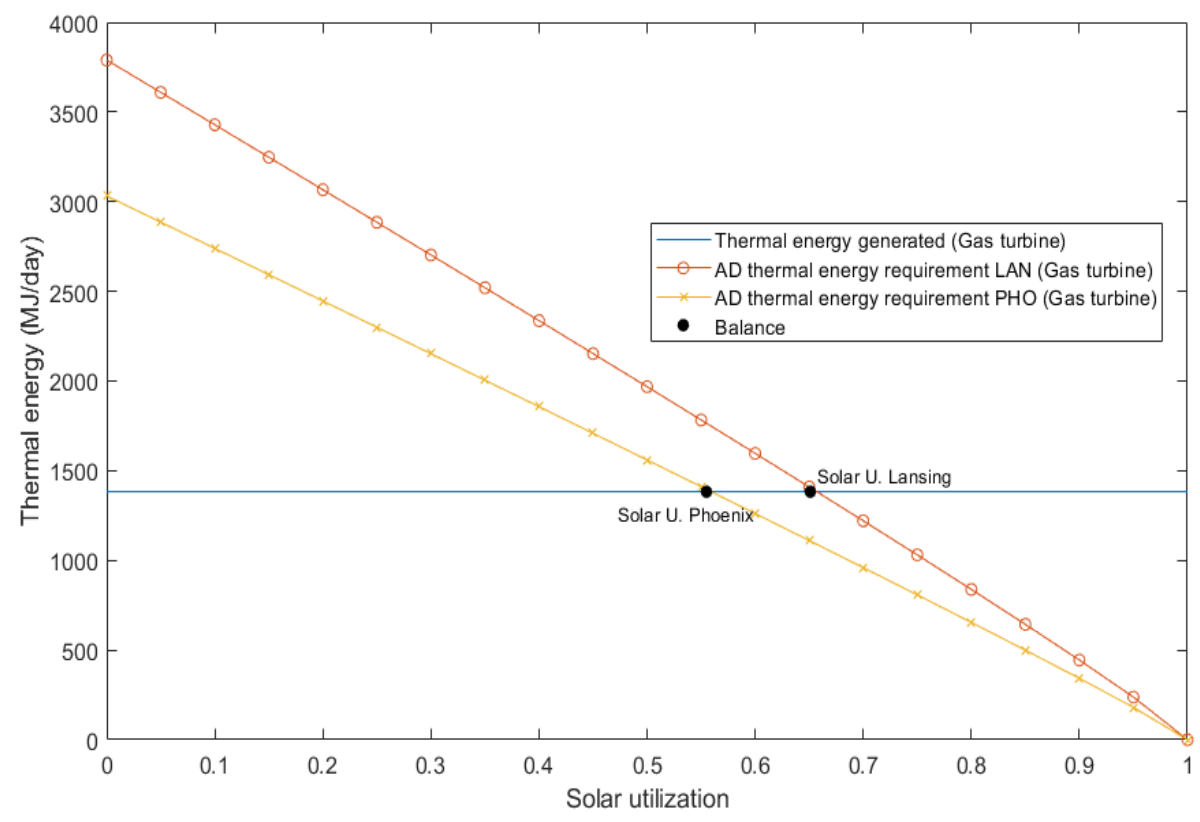

(b)

Figure 5. Relationship between solar utilization and thermal energy required by anaerobic digestion (AD) for the solar-bio-hybridization systems *: (a) steam turbine system; (b) gas turbine system; * the net capacity factor of 0.5 is used for the calculation.

\subsection{Selection of Solar Thermal Collectors for the Hybrid Systems}

Selection of solar thermal collectors for solar-bio-hybrid systems are based on the desirable temperature of the heat fluid for the steam and gas turbines. Central tower, parabolic dish, and parabolic trough are three most popular solar thermal collection technologies $[3,4,14]$. Central tower solar collection can reach extreme high temperature (above $1000{ }^{\circ} \mathrm{C}$ ), but requires a large footprint to accommodate solar reflectors, which is not suitable for small-scale solar power generation. While, the parabolic dish as a high temperature $\left(500-900^{\circ} \mathrm{C}\right)$ solar thermal collection and parabolic trough as a medium temperature $\left(200-400^{\circ} \mathrm{C}\right)$ collection are more suitable for small-scale solar power generation [14]. Con- 
sidering the required temperature of the heating fluid from steam $\left(220^{\circ} \mathrm{C}\right)$ and gas turbines $\left(840^{\circ} \mathrm{C}\right)$, the parabolic dish and parabolic trough are selected to be integrated with gas and steam turbines, respectively, for the small-scale solar-bio-hybrid power generation systems.

It has been reported that the optical efficiencies for parabolic trough and parabolic dish are approximately 0.76 and 0.93 , respectively $[14,29]$. Solar concentration ratio $\left(C_{r}\right)$ is another important parameter for solar thermal collectors and expressed as the absorber area $\left(A_{a}\right)$ vs. collector area $\left(A_{c}\right)$. Values of 70 and 750 are used as the concentration ratios for the corresponding parabolic trough and parabolic dish collectors [14,30].

Based on the collector type, working fluid temperature, and solar concentration ratio, the solar energy for the integration in the hybrid system can be calculated by the following equation:

$$
Q_{s}=D N I \cdot A_{c}-Q_{s ~ o p t}-Q_{s \text { rec }}-Q_{\text {s pipe }}
$$

where $Q_{s}$ is the solar heat collected (W), DNI is the direct normal irradiance at a given location (W/ $\mathrm{m}^{2}$ hourly based) $A_{c}$ is the collector area $\left(\mathrm{m}^{2}\right), Q_{\text {s opt }}$ is the heat loss due to optical losses $(\mathrm{W}), Q_{s}$ rec is the heat loss in solar receiver $(\mathrm{W})$, and $Q_{s}$ pipe is the heat loss in fluid conduction through pipes (W). Models for solar collection system were obtained from references [31,32].

In addition, working fluids (water and air) have a large impact on the heat exchanger effectiveness. The overall heat transfer coefficient (the capability of heat exchanger to transfer thermal energy) of water is several orders of magnitude higher than that of air $[33,34]$; the thermal efficiency of air is correspondingly lower than water. Values of 0.70 and 0.85 are selected by this study as $\varepsilon_{H E}$ for gas and water, respectively. Therefore, the heat that working fluid transfers from the absorber to the boiler and burner can be calculated as:

$$
Q_{S H E}=Q_{S} \cdot \varepsilon_{H E}
$$

where $Q_{S H E}$. is energy transferred (W) from absorber to working fluid and $\varepsilon_{H E}$ is the heat exchanger effectiveness. Solar collector areas required by the solar-bio-hybrid systems to generate $30 \mathrm{~kW}$ electricity under different net capacity factors are presented in Figure 6.

For the selected net capacity factor of 0.5 , the required solar collector area of the steam turbine at Lansing is $549 \mathrm{~m}^{2}$. At Phoenix, the steam turbine system does not require solar collectors due to the positive balance between the heat generated from the digestion and the heat required to maintain reactor temperature (Table 5). For the case of the gas turbine, the required solar collector area is $244.45 \mathrm{~m}^{2}$ at Phoenix. However, the gas turbine system cannot achieve a net capacity factor of 0.5 at Lansing, even though the solar collector area is increased to $700 \mathrm{~m}^{2}$ (Figure $6 \mathrm{~b}$ and Table 5). This occurs due to the absence of long-term thermal energy storage for solar radiation as well as high thermal energy demand. Without long-term thermal storage, the collected energy is not able to satisfy continuous thermal energy demand of $111.31 \mathrm{~kW}$ for the gas turbine [35].

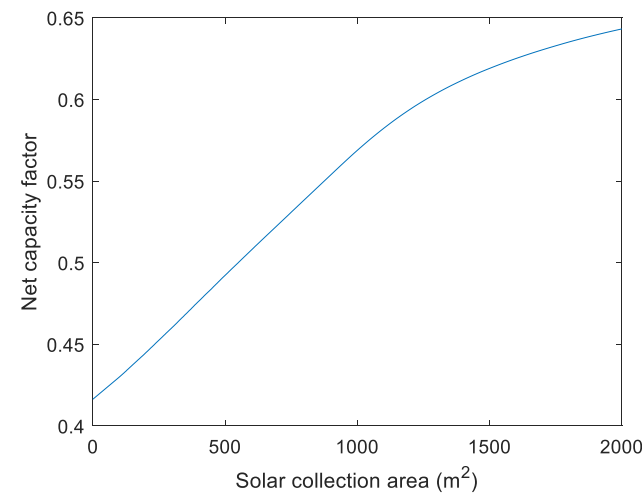

(a)

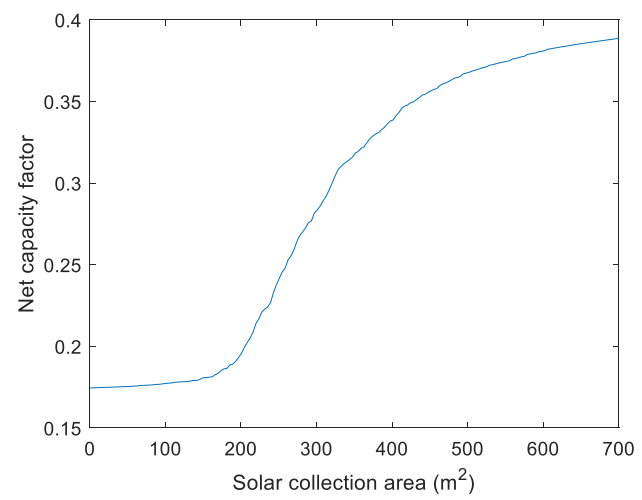

(b)

Figure 6. Cont. 


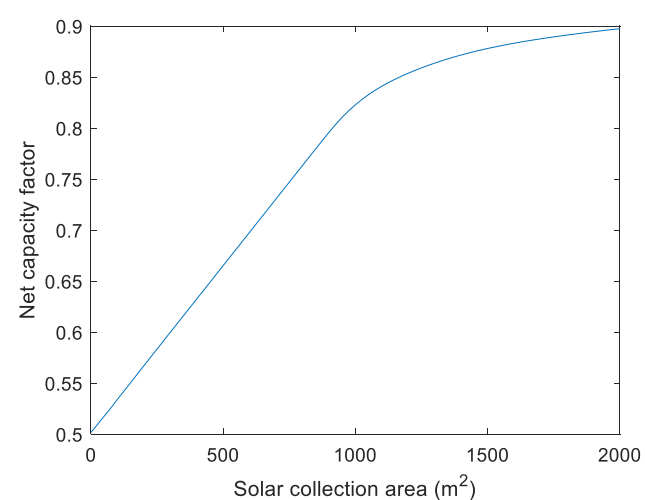

(c)

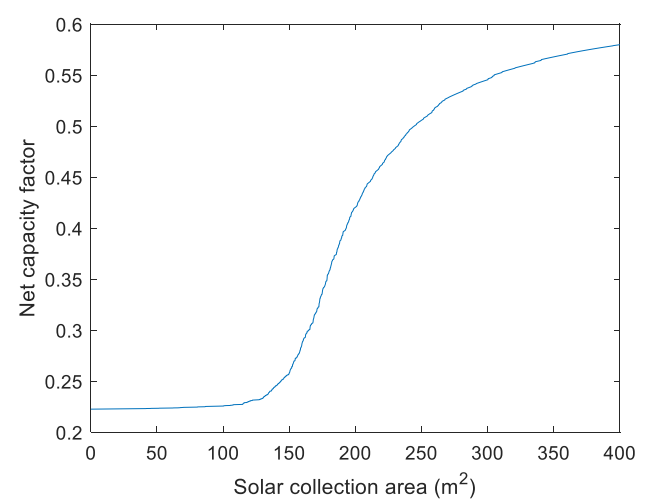

(d)

Figure 6. Net capacity factor as function of solar collection area: Lansing, (a) steam (parabolic trough), and (b) gas (parabolic dish) turbines; Phoenix, (c) steam (parabolic trough), and (d) gas (parabolic dish) turbines.

Table 5. Required solar collector areas for steam and gas turbines at two locations in the coldest winter day under the selected net capacity factor (NCF).

\begin{tabular}{ccc}
\hline \multirow{2}{*}{ Location } & \multicolumn{2}{c}{ Solar Collector Area $\mathbf{( m}^{\mathbf{2}}$ ) } \\
\cline { 2 - 3 } & Steam (Parabolic Trough) & Gas (Parabolic Dish) \\
\hline \multirow{2}{*}{ Lansing } & 549 (NCF: 0.50) & 320 (NCF: 0.30) \\
& 0 (NCF: 0.50) & (NCF: 0.50) \\
\hline Phoenix & &
\end{tabular}

\section{Discussion}

The system analysis shows the relationship between net capacity factor, digester volume, solar thermal utilization, and geographic location for both Brayton and Rankine cycles. According to system configurations (Figure 1), the required highest temperatures in individual thermal cycles determine solar collector technologies that could be integrated into the solar-bio-hybrid power generation systems. In the case of the steam turbine (Rankine cycle), the maximum temperature (turbine inlet) is $200{ }^{\circ} \mathrm{C}$ (Figure 1b), which could be achieved by medium-temperature solar thermal technologies such as the parabolic trough used by this study. However, the working fluid in gas turbine (Brayton cycle) needs to be heated by solar thermal energy from $548.73{ }^{\circ} \mathrm{C}$ at the outlet of the regenerator to $843.85^{\circ} \mathrm{C}$ before the burner (Figure 1d). High-temperature solar thermal technologies such as the parabolic dish selected by this study (the surface area of a parabolic dish ranging from 43 to $117 \mathrm{~m}^{2}$ ) have to be used to satisfy the need of such temperature increase [36,37]. It is a limiting factor to further increase solar thermal energy utilization in the gas turbine hybrid system. Even though it is theoretically achievable to raise the temperature at the absorber of parabolic dish to above $1000{ }^{\circ} \mathrm{C}$ by extending the area of reflection, fabricating such large parabolic dishes may pose some manufacture and installation difficulties as well as economic barriers for small-scale applications.

Since solar radiation and ambient temperature significantly vary between seasons and locations, digester volume must be large enough in order to produce more biogas to satisfy the system energy demand once solar thermal energy is not able to fulfill the heating requirement (i.e., in the winter months at Lansing). This is the reason that the minimum solar utilization value for the system design is selected by this study based on maintaining the average net capacity factor of 0.5 in a year. Moreover, due to thermodynamic difference in fuel efficiency between gas and steam turbines, required digester volumes are different for the hybrid systems. The fuel efficiency of the gas turbine $(26.95 \%)$ is much higher than that of the steam turbine (5.62\%). The corresponding digester in the steam turbine hybrid system is approximately 10 times bigger than the one in the gas turbine hybrid 
system (Table 4). The simulation results also demonstrate that the solar-bio-hybrid steam turbine system requires less solar collector area $\left(549 \mathrm{~m}^{2}\right.$ and $0 \mathrm{~m}^{2}$ for Lansing and Phoenix, respectively) than the gas turbine system $\left(700 \mathrm{~m}^{2}\right.$ and $244.45 \mathrm{~m}^{2}$ for Lansing and Phoenix, respectively) (Table 5). It is mainly caused by higher values of the solar utilization factor for the gas turbine systems. The global efficiency (electricity and heat outputs vs. biogas and solar energy inputs) of the solar-bio-hybrid steam turbine system $(67.7 \%)$ is higher than the solar-bio-hybrid gas turbine system (55.7\%).

The overall energy balance for an annual operation elucidates comprehensive energy distribution profiles for both power generation systems (Figure 7). Compared to the hybrid steam turbine systems, the hybrid gas turbine system in both locations requires more solar energy than biogas to compensate thermal losses and realize thermal energy balance (Figure $7 \mathrm{~b}, \mathrm{~d}$ ). On the contrary, the steam turbine system has better performance on energy balance (Figure 7a,c). Particularly at Phoenix, biogas is enough at the net capacity factor of 0.5 to realize the target energy output of $30 \mathrm{~kW}$ without need of solar energy input (8421 GJ per year from biogas), which means the net capacity factor can be increased (more than 0.5) for the solar-steam power system to generate more energy at Phoenix.

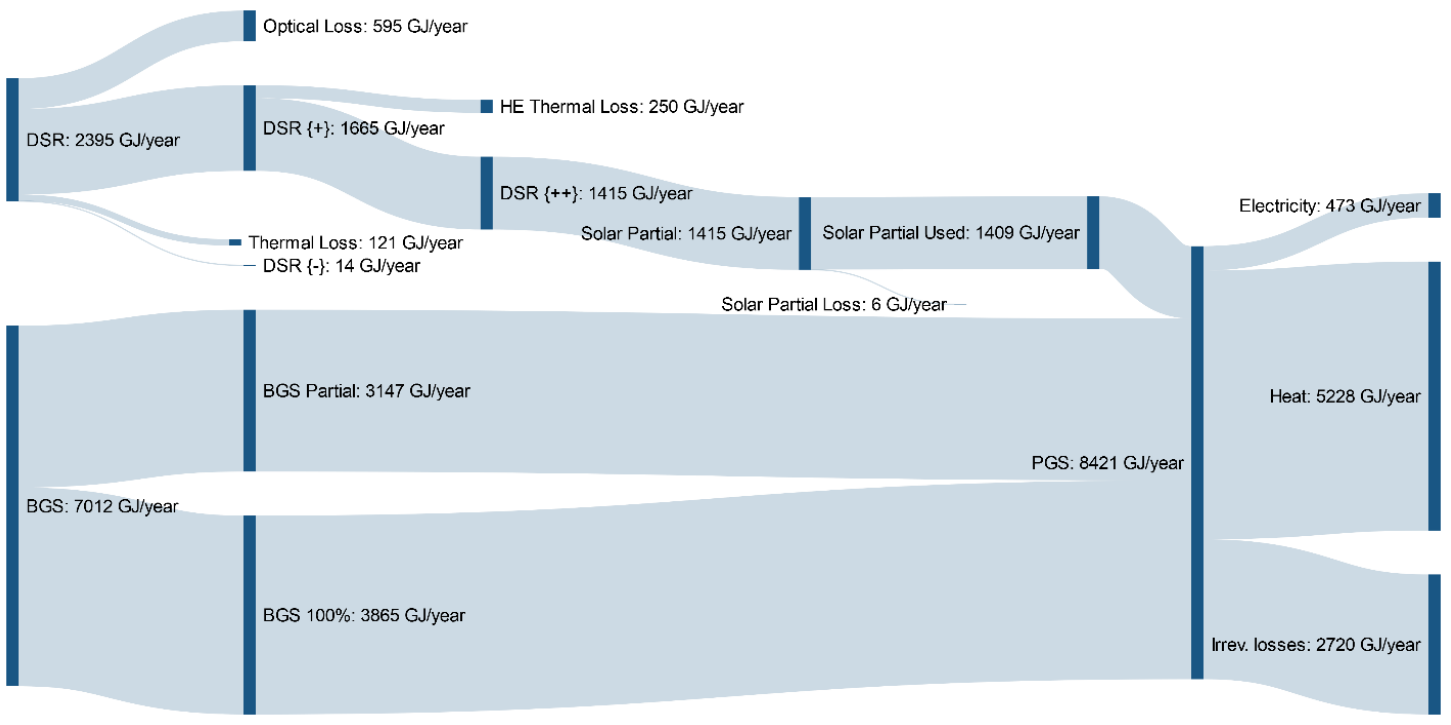

(a)

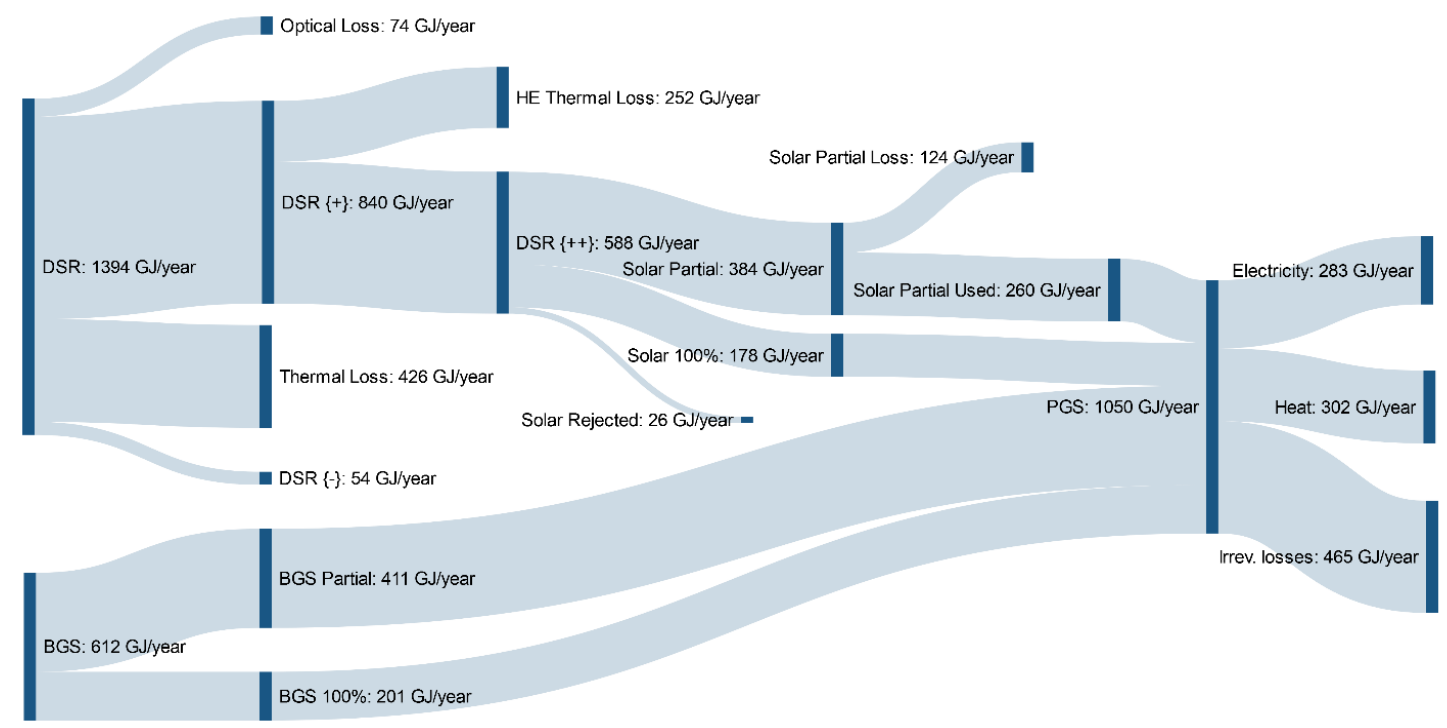

(b)

Figure 7. Cont. 


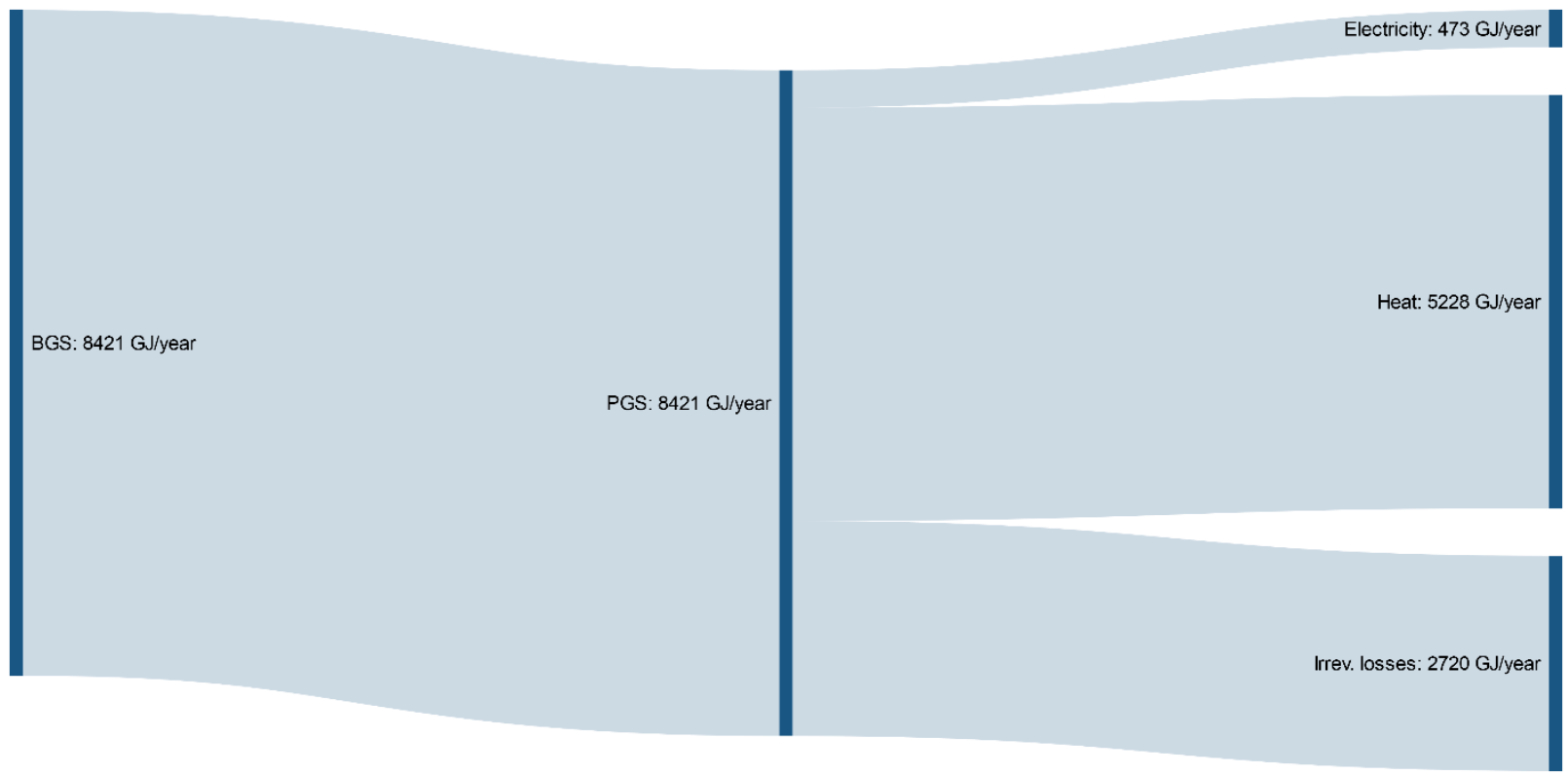

(c)

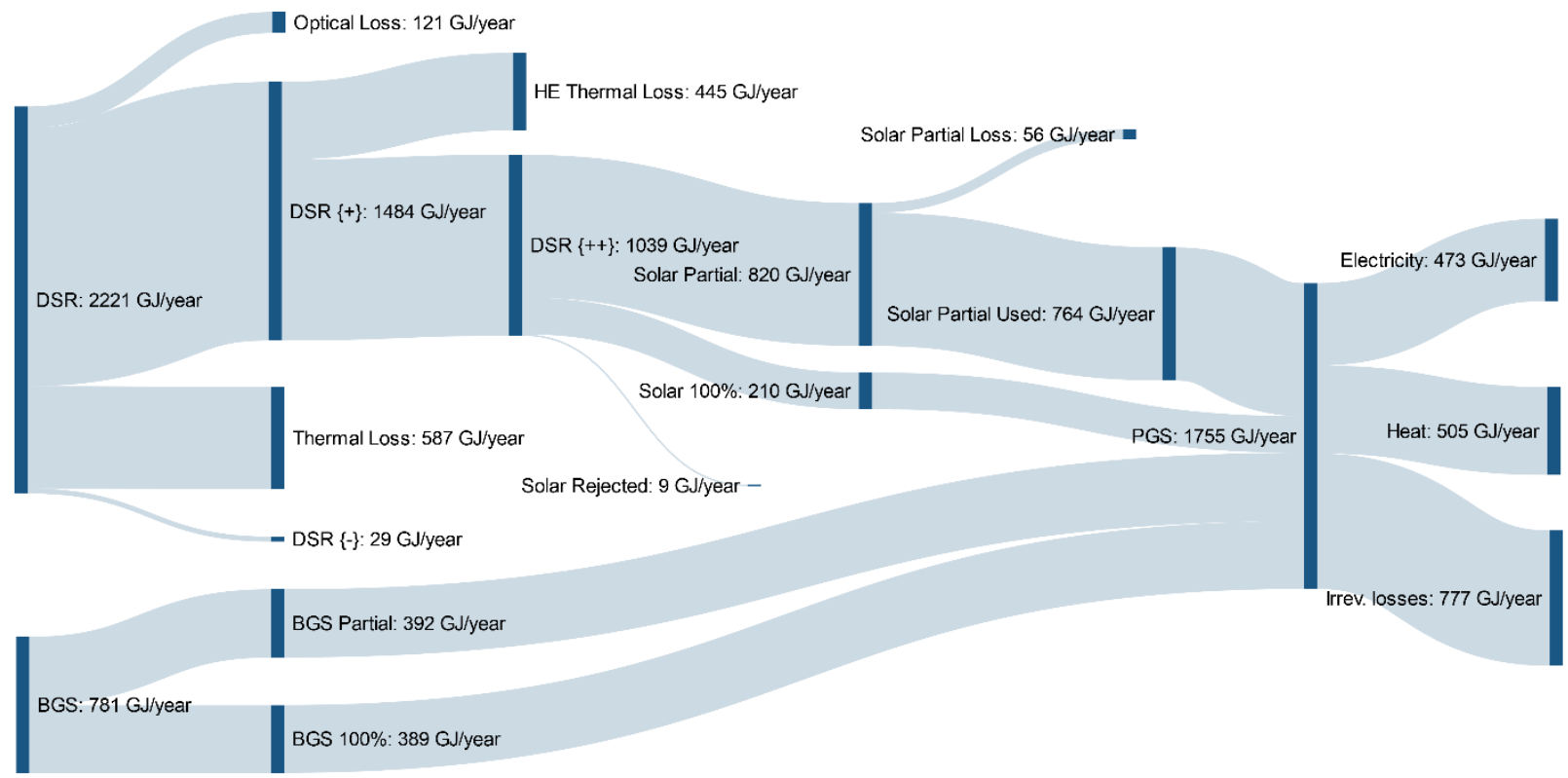

(d)

Figure 7. Energy balance of small-scale solar-bio-hybrid power generation systems*: (a) steam power generation system in Lansing, (b) gas power generation system in Lansing (c) steam power generation system in Phoenix (d) gas power generation system in Phoenix. *: DSR: Available direct solar radiation; Optical Loss: Energy loss due to optical properties in the concentrator-collector system; Thermal Loss: Energy loss due to radiation, conduction, and convection in the concentrator-collector system; DSR \{-\}: Solar energy not collected due to thermal losses cause temperatures in the working fluid lower than the required by turbine system; DSR $\{+\}$ : Useful solar energy collected; HE: Thermal energy loss in the heat exchangers; DRS $\{++\}$ : Solar energy transferred to thermal working fluid (water or air); Solar Rejected: Energy that cannot be used due to it exceeding the maximum requirement by the turbine system; Solar $100 \%$ : Solar energy used to completely power the turbine system; Solar Partial: Solar energy collected and stored in a short-term device which is not enough to power the system by itself; Solar Partial used: Solar energy used in combination with biogas; Solar Partial Loss: Solar energy collected but not used due to the fact that biogas is not available to complement the thermal requirement; BGS: Energy obtained from biogas combustion; BGS Partial: Energy from biogas used in combination with solar energy; BGS 100\%: Biogas used to completely power the turbine system; PGS: Power generation system; Irrev. Losses: Irreversible losses in the PGS. 
The analysis in this study is based upon solar thermal energy as a supplemental energy source to facilitate utilization of biofuel-biogas and indirectly improve system power generation performance. As a matter of the fact, the net capacity factor can be significantly increased if solar thermal energy can be directly utilized as a single energy source in thermodynamic cycle for several hours per day (once solar radiation is able to bring the working fluid to desired temperatures for gas and steam turbines). Further studies are needed to explore such scenarios.

\section{Conclusions}

This study conducted a comprehensive analysis on small-scale solar-bio-hybrid power generation $(30 \mathrm{~kW})$. The relationship between net capacity factor, solar utilization efficiency, and biogas utilization efficiency was delineated. The analysis concludes that the hybrid steam turbine system has better global thermal efficiency $(67.7 \%)$ than the hybrid gas turbine system $(55.7 \%)$, and the hybrid gas turbine system has better electricity generation efficiency $(26.95 \%)$ than that $(5.62 \%)$ of the hybrid steam turbine system. This study also provides a method systematically applying three parameters of net capacity factor, solar utilization efficiency, and biogas utilization efficiency to analyze performance and elucidate preferred configuration of solar-bio-power generation process, which can be used to study and optimize other hybrid systems.

Author Contributions: Conceptualization, M.B. and W.L.; methodology, M.B.; validation, M.B., A.E., and W.L.; formal analysis, M.B.; investigation, M.B. and W.L.; data curation, M.B.; writing-original draft preparation, M.B. and W.L.; writing-review and editing, M.B., A.E., and W.L.; visualization, M.B.; supervision, W.L.; project administration, W.L.; funding acquisition, A.E. and W.L All authors have read and agreed to the published version of the manuscript.

Funding: This research was funded by the U.S. Department of Defense Strategic Environmental Research and Development Program (W912HQ-12-C-0020).

Institutional Review Board Statement: Not applicable.

Informed Consent Statement: Not applicable.

Data Availability Statement: The data presented in this study are available on request from the corresponding author.

Acknowledgments: The authors would also like to thank the AgBioResearch at Michigan State University for funding this work through faculty salaries.

Conflicts of Interest: The authors declare no conflict of interest.

\section{References}

1. Zhao, Y.; Hong, H.; Jin, H. Mid and low-temperature solar-coal hybridization mechanism and validation. Energy 2014, 74, 78-87. [CrossRef]

2. Pihl, E.; Spelling, J.; Johnsson, F. Thermo-economic optimization of hybridization options for solar retrofitting of combined-cycle power plants. J. Sol. Energy Eng. 2014. [CrossRef]

3. Jamel, M.S.; Abd Rahman, A.; Shamsuddin, A.H. Advances in the integration of solar thermal energy with conventional and non-conventional power plants. Renew. Sustain. Energy Rev. 2013, 20, 71-81. [CrossRef]

4. Popov, D. Innovative solar augmentation of gas turbine combined cycle plants. Appl. Therm. Eng. 2014, 64, 40-50. [CrossRef]

5. Colmenar-Santos, A.; Bonilla-Gomez, J.L.; Borge-Diez, D.; Castro-Gil, M. Hybridization of concentrated solar power plants with biogas production systems as an alternative to premiums: The case of Spain. Renew. Sustain. Energy Rev. 2015, 47, 186-197. [CrossRef]

6. San Miguel, G.; Miguel, G.S.; Corona, B. Hybridizing concentrated solar power with biogas and biomethane as an alternative to natural gas: Analysis of environmental performance using LCA. Renew. Energy 2014, 66, 580-587. [CrossRef]

7. Schwarzbözl, P.; Buck, R.; Sugarmen, C.; Ring, A.; Marcos Crespo, M.; Altwegg, P.; Enrile, J. Solar gas turbine systems: Design, cost and perspectives. Sol. Energy 2006, 80, 1231-1240. [CrossRef]

8. Selwynraj, A.I.; Iniyan, S.; Polonsky, G.; Suganthi, L.; Kribus, A. An economic analysis of solar hybrid steam injected gas turbine (STIG) plant for Indian conditions. Appl. Therm. Eng. 2015, 75, 1055-1064. [CrossRef]

9. Livshits, M.; Kribus, A. Solar hybrid steam injection gas turbine (STIG) cycle. Sol. Energy 2012, 86, 190-199. [CrossRef]

10. Buck, R.; Friedmann, S. Solar-Assisted Small Solar Tower Trigeneration Systems. J. Sol. Energy Eng. 2007, 129, 349. [CrossRef] 
11. Koai, K.; Lior, N.; Yeh, H. Performance analysis of a solar-powered/fuel-assisted Rankine cycle with a novel 30 hp turbine. Sol. Energy 1984, 32, 753-764. [CrossRef]

12. Caruana, D.J.; Olsen, A.E. Anaerobic Digestion: Processes, Products, and Applications; Nova Science Publishers: New York, NY, USA, 2012.

13. USDA, National Agricultural Statistics Service. Farms, Land in Farms, and Livestock Operations. Available online: https: //www.nass.usda.gov/Publications/Todays_Reports/reports/fnlo0211.pdf (accessed on 15 April 2018).

14. Reddy, V.S.; Kaushik, S.C.; Ranjan, K.R.; Tyagi, S.K. State-of-the-art of solar thermal power plants-A review. Renew. Sustain. Energy Rev. 2013, 27, 258-273. [CrossRef]

15. Chen, R.; Roos, M.M.; Zhong, Y.; Marsh, T.; Roman, M.B.; Ascencio, W.H.; Uribe, L.; Lorio, L.U.; Kirk, D.; Reinhold, D.M.; et al Responses of anaerobic microorganisms to different culture conditions and corresponding effects on biogas production and solid digestate quality. Biomass Bioenergy 2016, 85, 84-93. [CrossRef]

16. Sun, Q.; Li, H.; Yan, J.; Liu, L.; Yu, Z.; Yu, X. Selection of appropriate biogas upgrading technology-A review of biogas cleaning, upgrading and utilisation. Renew. Sustain. Energy Rev. 2015, 51, 521-532. [CrossRef]

17. Halotechnics. High Temperature Thermal Fluids. Available online: http://www.halotechnics.com/products/ (accessed on 30 October 2015).

18. NextGrid NextGrid CHP Models. Available online: http://www.gonextgrid.com/products/nextgrid-chp-models / (accessed on 4 October 2020).

19. Liu, A.; Weng, Y. Effects of Lower Heat Value Fuel on the Operations of Micro-Gas Turbine. Energy Power Eng. 2009, 1, 28-37. [CrossRef]

20. Li, Y.; Weng, Y. Performance study of a solid oxide fuel cell and gas turbine hybrid system designed for methane operating with non-designed fuels. J. Power Sources 2011, 196, 3824-3835. [CrossRef]

21. Capstone Turbine Corporation. Technical Reference: Capstone Model C30 Performance. 2006. Available online: https://www. capstoneturbine.com/ (accessed on 4 October 2020).

22. Bakalis, D.P.; Stamatis, A.G. Incorporating available micro gas turbines and fuel cell: Matching considerations and performance evaluation. Appl. Energy 2013, 103, 607-617. [CrossRef]

23. Cleaver-Brooks, Model CB: 15-100 HP Steam and Hot Water Dryback Integral Burner. 2011. Available online: https:// cleaverbrooks.com/ (accessed on 3 October 2020).

24. Olivenza-Leon, D.; Medina, A.; Hernandez, A.C. Thermodynamic modeling of a hybrid solar gas-turbine power plant. Energy Convers. Manag. 2015, 93, 435-447. [CrossRef]

25. U.S.ClimateData, Temperature-Precipitation-Sunchine-Snowfall. Available online: http://www.usclimatedata.com/ (accessed on 19 March 2015).

26. NREL. NSRDB Data Viewer. Available online: https://maps.nrel.gov/nsrdb-viewer/ (accessed on 28 April 2018).

27. Yue, Z.; MacLellan, J.; Liu, Y.; Liao, W. Effects of corn stover as carbon supplement on an integrated anaerobic digestion and ethanol fermentation process. J. Renew. Sustain. Energy 2013, 5, 063116-063116-9. [CrossRef]

28. Zhong, Y.; Roman, M.B.; Zhong, Y.; Archer, S.; Chen, R.; Deitz, L.; Hochhalter, D.; Balaze, K.; Sperry, M.; Werner, E.; et al. Using anaerobic digestion of organic wastes to biochemically store solar thermal energy. Energy 2015, 83, 638-646. [CrossRef]

29. Giostri, A.; Binotti, M.; Silva, P.; Macchi, E.; Manzolini, G. Comparison of Two Linear Collectors in Solar Thermal Plants: Parabolic Trough Versus Fresnel. J. Sol. Energy Eng. 2013, 135, 011001. [CrossRef]

30. Skouri, S.; Bouadila, S.; Salah, M.B.; Nasrallah, S.B. Comparative study of different means of concentrated solar flux measurement of solar parabolic dish. Energy Convers. Manag. 2013, 76, 1043-1052. [CrossRef]

31. NREL. System Advisor Model; Software version 2016.3.14 64 bit; National Renewable Laboratory, 2016. Available online: https: / / sam.nrel.gov / download/version-2016-3-14.html (accessed on 15 June 2020).

32. Fraser, P. Stirling Dish System Performance Prediction Model. Mechanical Engineering Department, University of Wisconsin, Madison, 2008. Available online: https://sam.nrel.gov/concentrating-solar-power/csp-publications.html (accessed on 19 July 2020).

33. Kakaç, S.; Liu, H. Heat Exchangers: Selection, Rating, and Thermal Design; CRC Press: Boca Raton, FL, USA, 1998.

34. Çengel, Y.A. Heat Transfer: A Practical Approach; WBC McGraw-Hill: Boston, MA, USA, 1998.

35. Bustamante, M.; Liao, W. A self-sustaining high-strength wastewater treatment system using solar-bio-hybrid power generation. Bioresour. Technol. 2017, 234, 415-423. [CrossRef] [PubMed]

36. Mancini, T.; Heller, P.; Butler, B.; Osborn, B.; Schiel, W.; Goldberg, V.; Buck, R.; Diver, R.; Andraka, C.; Moreno, J. Dish-Stirling systems: An overview of development and status. J. Sol. Energy Eng. Trans. ASME 2003, 125, 135-151. [CrossRef]

37. Baharoon, D.A.; Rahman, H.A.; Omar, W.Z.W.; Fadhl, S.O. Historical development of concentrating solar power technologies to generate clean electricity efficiently-A review. Renew. Sustain. Energy Rev. 2015, 41, 996-1027. [CrossRef] 